\title{
Homeownership in Slovenia: Searching for an alternative theory on its excessive growth
}

Recent studies generally show growing levels of homeownership across Europe. However, a comparison of statistical data shows a stark difference in the extent of homeownership between western Europe versus central and eastern Europe. Whereas the development and growth of homeownership in western Europe has been extensively discussed in the literature and various theories have been advanced, its strong dominance in central and eastern Europe has been barely examined. Due to the lack of thorough discourse on this topic, there thus continues to be a void in the literature, which is manifested in the absence of a sound explanation for the comparatively much higher expansion of homeownership in post-communist central and eastern Europe. This article contributes to filling this gap. The central argument is that theories that were developed to explain the growth of homeownership in western Europe (economies with a capitalist tradition) might not necessarily apply to situations in central and eastern Europe (with previous communist centrally planned economies). Focusing on the case of Slovenia, the discussion is orientated towards developing an alternative theory that may be more relevant in explaining and understanding the growing preference for homeownership in the country.

Keywords: homeownership, communism, housing policy, self-construction, family house, Slovenia 


\section{Introduction}

A literature review shows steady growth in homeownership levels in recent decades in many European countries. These increases have been particularly high in central and eastern Europe (Poland 63\%, Czech Republic 75\%, Latvia 83\%, Slovenia $90 \%$, Hungary $94 \%$, Slovakia $92 \%$, Estonia $96 \%$, Romania, 96\%, etc.) as compared to western Europe (Finland 66\%, Netherlands 58\%, France 57\%, Austria 56\%, Denmark 46\%, Germany 46\% and Sweden 38\%; Dol \& Haffner 2010). Similarly, European Mortgage Federation data (EMF, 2015) show considerably higher levels of owner-occupation in central and eastern Europe in comparison to western Europe. Franklin Obeng-Odoom's (2016) study of immigrants reveals that similar tendencies for homeownership may also be observed among central and eastern European immigrants that migrate to cities overseas. According to Peter Saunders (1990: 2), "mass homeownership is associated with a strong popular desire to own personal property and is underpinned by deeply cherished and widespread values which emphasise independence, security and the importance of home as a base from which to venture out into the world".

Saunder's observation offers a suitable initial explanation to the popular belief that the large majority of Slovenians aspire to live in their own home. Various surveys conducted in Slovenia on this phenomenon have revealed that on average over $90 \%$ of respondents aspire to live in their own house, a detached house with a private garden being the most desired type (Kos, 1984; Mandič 1992). Other than being a natural aspiration, owning a house is also believed to be a major indicator of social status. It is therefore often suggested that the strong desire to own a home is subtly fuelled by the urge to achieve this ultimate social status symbol (Michalovic, 1992). Especially in the US, owning a home is a life-long ambition that one pursues in order to achieve the socially expected standard. This objective has been described by some authors as the "ultimate American dream" (Retsinas \& Belsky, 2002; Rohe et al., 2002; Shlay, 2006). In his study on the subject, Anthony Gurney (1999) concluded that homeownership in the UK is increasingly seen as "the norm", whereas rental tends to be looked upon as a tenure for the underprivileged. Along the same line of reasoning, Moira Munro (2007) suggests that there appears to be a popular association between owner occupation and success, status and wealth.

In addition to the social status explanation, however, other authors have pointed to the social benefits of homeownership to both the owner and society (e.g., Megbolugbe \& Linneman, 1993; Rohe \& Stewart, 1996; Rossi \& Weber, 1996; DiPasquale \& Gleaser, 1999; Rohe, Zandt \& McCarthy, 2001; Elsinga \& Hoekstra, 2005; Hajer, 2009; McCabe, no date).
The common theme here is that homeownership offers greater independence, security and pride of possession, strengthens local social networks, contributes to social involvement and has a positive impact on the neighbourhood.

Whether homeownership in Slovenia is all or any of the above, or the result of some other cause, the fact is that it currently accounts for over $90 \%$ of the total housing stock (Statistical Office of the Republic of Slovenia, 2012). Of this, 65\% is "family houses". (I use the term family house instead of the more common term single-family house because family houses in Slovenia are, in the majority of cases, constructed with the aim of accommodating more than one family.) This article mainly focuses on the family house as the most characteristic and predominant form of homeownership. It starts with a review of the (western European) theories that mostly blame government policies for the growth of homeownership. This review particularly focuses on Saunders' (1990) comprehensive study of various theories on homeownership and its growth in Europe. This is followed by a brief review of literature exploring the potential of homeownership as a source of wealth, or the "asset-based notion" of homeownership (Kemeny, 1981, 2005; Ball, 1983; Ronald 2008; Doling \& Ronald 2010; Elsinga \& Mandič 2010; Mandič, 2010; Toussaint 2011). The section discussing the homeownership situation in Slovenia examines the nature of homeownership in detail and the major factors that influenced its development and growth. I discuss the most important mechanism for facilitating family house ownership: self-construction. Self-construction was also the main form of private provision in Bulgaria (Koleva \& Dandolova, 1992), and a typical form of provision in Hungary, especially in rural areas and "with some significance also in urban areas” (Hegedüs \& Tosics, 1992; Hegedüs, Mark \& Tosics, 1996). Self-construction is a popular mechanism for securing homeownership worldwide, especially in lower-income countries (Gilbert \& Varley, 1990; Gilbert, 1999).

Linking this with self-construction practices, I discuss and suggest alternative explanations to argue against another widely promoted explanation of the surge in homeownership in Slovenia. This concerns the popular conviction that family house building practices expanded in the country because this was the only secure form of financial investment under communist rule, which lasted from the end of the Second World War until the early 1990s. The advocates of this theory believe that the growth of homeownership in Slovenia is the consequence of a political system that did not offer people alternatives for investing their surplus income (e.g., Hegedüs \& Tosics, 1992; Mandič, 1992). On the contrary, with the help of statistical data I argue and show that the urge to own family houses did not, in any way, lessen even after the adoption of a market economy and introduction of various long- and short-term 
investment schemes, such as shares, bonds, mutual funds, pension funds and so on.

The article thus examines the validity in Slovenia of various homeownership theories that were previously advanced to describe the development and dominance of homeownership in western Europe. The final aim is to lay a foundation for a viable theoretical explanation that may help in better understanding the causes of the apparently unstoppable urge to own, which threatens to gradually wipe out rental tenure entirely. This information is necessary as a premise for formulating policies to address the problem and establish a more appropriate tenure structure. It is also hoped that the alternative explanations discussed will provide a useful theoretical framework for future discourse on the subject.

\section{Theoretical background}

Theory 1: Homeownership as a product of deliberate government policies

The growth of homeownership first needs to be investigated from a historical perspective. Saunders' (1990) study is especially useful because it offers a comprehensive historical analysis of the development and expansion of homeownership in the western world. The study presents a broad range of views by numerous scholars that have advanced various theoretical explanations for the occurrence and growth of homeownership. These theories are summarised below.

Saunders' historical review mostly comprises theories by Marxist writers, who generally argued that owner-occupation was intentionally fostered by governments or capitalist interests to "bolster the bourgeois social order". He identifies five main reasons suggested by various theorists to explain why the "capitalist class, aided and abetted by the capitalist state, sought to draw the working class into home ownership" (Saunders 1990: 29). These are:

Ideological effects of homeownership. Various authors have suggested that post-Second World War housing policies had the deliberate intention of making every worker a small homeowner to secure working-class support for the private property system enjoyed by the wealthier classes. It is explained that such measures sought to induce workers to identify with bourgeois values. The essence of this theory is that encouraging owner-occupation ensures both social stability and future political support.

Creation or reinforcement of divisions. The second theory holds that owner-occupation was encouraged to create divisions within the working class. In this case, the aim is to enable the higher strata of the working class to achieve homeownership, so as to detach them from the rest of their class, which in turn would result in weakening proletarian solidarity and defusing the resentment of capital.

Long-term date effect. According to this theory, offering skilled workers small suburban homes to be purchased through home mortgages was a strategy employed by industrialists after the Second World War in order to achieve greater industrial order. Tying house buyers into a twenty- or thirty-year financial commitment was believed to discourage potential strike action, which would likely result in a loss of regular income and therefore the eventual loss of one's home.

Individualisation and privatisation of the working class. Here, it is believed that homeownership encourages workers to withdraw from collective life and focus more on their home and family. Homeownership is thus believed to have been deliberately encouraged with the aim of individualising and privatising the working class.

Creation of a mass market for consumer goods. The proponents of this theory see the privately owned home as being at the core of contemporary consumerism. Owner-occupation is supported and encouraged to stimulate demand for building materials, enhance demand for car use, increase energy consumption and increase demand for consumer goods. It argues that homeownership has created new lifestyles dependent on an insatiable demand for consumer durables, which can only be satisfied by expanding industrial production. Increasing the level of homeownership therefore has the ultimate aim of increasing consumerism in order to generate more national revenue.

Saunders' general conclusion is that Marxist theorists believe that the development and expansion of homeownership is the result of government policies that were implemented with the intention "to fragment the working-class collective and dupe individual workers into accepting the legitimacy of the upperclass social relations" (Saunders, 1990: 65). He rejects all of these theories, arguing that they lack evidence to show, first, that working-class homeownership was successfully implemented or, second, that this was the government's intention. Instead, he suggests that homeownership is an aspiration that needs to be examined and understood in terms of human behaviour. Saunders' rejection of the premeditated government role described above finds support in the work of Anthony Giddens (1984), who noted that it is not always possible to motivate and control people's actions. Even when such an attempt is made, he argued, one cannot guarantee the eventual achievement of the intended outcomes. The crucial weakness of these theories is the inherent assumption that the working 
class can always be manipulated to act precisely as anticipated and deliver the exact outcomes intended by the ruling class.

One can take the risk of suggesting that the theories reviewed above are too simplistic to be acceptable as credible explanations of the growth of homeownership, even in the western $\mathrm{Eu}-$ ropean context. This article argues that they are certainly not relevant in explaining the growth of homeownership in Slovenia. In fact, these theories could not apply to Slovenia because they were developed by Marxist scholars to explain situations in capitalist countries. These theories are essentially flawed and totally inapplicable to countries that, at the time, were under communist rule. Communist regimes did not seek to establish a private property system, weaken proletarian solidarity or individualise the working class, and housing mortgages were also not available. Communist doctrine sought exactly the opposite; that is, to unite the proletariat for the common good of the state. Moreover, although the creation of mass markets for consumer goods also cannot be denied in the former communist countries, it is vital to acknowledge that the principle aim was not to create homeownership-related consumerism, but to create jobs. Almost all new industrial development was simultaneously accompanied by the construction of collective, government-owned housing for the workers. Indeed, contrary to the legitimization of homeownership, the former communist countries of central and eastern Europe pursued housing policies that were fundamentally intended to thwart all forms of private ownership, including housing (Telegarsky \& Struyk, 1991; Turner, Hegedüs \& Tosics, 1992; Lowe \& Tsenkova, 2003; Donner, 2006; for Slovenia, see also Sendi, 1999, 2016).

Having rejected the validity of the Marxist theories on the roots and development of homeownership, it is fair to point out that there are other (not necessarily Marxist authors) that similarly see national policies as the major cause for the gradual (and recently intensified) expansion of homeownership worldwide. At the global level, the United Nations body responsible for housing development has disappointedly observed that the number of governments trying to support rental housing development has considerably declined. It has warned that " $[\mathrm{g}]$ overnments should not perpetuate the myth of the achievability of universal homeownership. Instead they should accept that at some point in their lives most people need rental accommodation" (UN-HABITAT, 2003: iii). The dominance of homeownership as a consequence of government policy has also been discussed by Alan Gilbert (1999), who has argued that homeownership has been popular with most governments because they have believed that most people prefer to own rather than to rent. He has further suggested that governments encourage and implement policies that enable homeownership in order to secure political support; that is, votes. The same line of thinking is pursued by
Munro (2007), who has written that in recent decades the UK has implemented policies (such as Right to buy or low cost home ownership) intended to increase homeownership "driven by the belief that such policies are popular with the electorate" (Munro, 2007: 243). The theory that seeks to explain the growth of homeownership as a government "trick" to secure voter support introduces a perspective different from those previously suggested by Marxist theorists. Consequently, how relevant is this theory to the Slovenian situation?

There is no doubt that national policies implemented in the past in a variety of forms have impacted the growth of homeownership in Slovenia. Faced with the fact that it would not be able to fully realise its self-imposed post-Second World War communist ideological commitment to provide housing for all of its citizens, in 1965 the government introduced a policy measure that marked the initial official recognition of private ownership of housing. The measure enabled individuals to purchase construction materials from government-owned building-material manufacturers at cheaper prices in the form of subsidies (Marinšek, 1983). This laid the ground for the intensification of self-construction activity in the following decades.

The privatisation of the previous rental housing stock between 1991 and 1994 certainly significantly contributed to increasing the level of homeownership. By the end of the privatisation process, the share of homeownership had grown from $67 \%$ in 1991 to $89 \%$ in 1994, an increase of $22 \%$ (Sendi, 2009). Other policy measures that focused on increasing the level of homeownership following the shift from a planned to market economy in 1991 included various forms of government-sponsored object and subject subsidies and a housing loan scheme (operating on the principles of the German Sparkassen mortgage lending model), which was introduced in 1999 and abandoned in 2006 (Cirman \& Sendi, 2016).

However, it must be noted that none of these measures could be described as an instrument introduced by the government with the deliberate intention to woo voters. The policy of subsidising building materials under communist rule was simply introduced as a pragmatic solution (Marinšek, 1983). Under the one-party system, political support for the government was naturally guaranteed and there was no need to implement particular policies (in any area) for ensuring it. Moreover, although the privatisation of the public housing stock had several objectives, securing voter support for the next elections was not one of them. ${ }^{[1]}$ Upon the introduction of the measure, the government was enjoying a very high level of public support, having just abandoned the unpopular planned economy system, which was crumbling all across eastern Europe at that time. With respect to the provision of subject and object subsi- 
dies after the adoption of a market economy, the analysis of the effect of these housing policy measures after fifteen years of implementation showed that they had had no noticeable impact on the level of production of new housing (Sendi, 2007). The calculations revealed that the amounts secured at the end of the saving period were too low to enable home seekers to purchase dwellings on the highly price-inflated housing market.

It may thus be concluded that the government has mostly played a passive and marginal role in this area and cannot be considered a major causal factor of the growth of homeownership in Slovenia. Government policies in this area have been nowhere near "bribing people to become homeowners", as Gilbert (2008: ii) labelled the policies that have been implemented in a variety of countries worldwide. I thus reject the theory that would seek to explain the growth of homeownership in Slovenia as the consequence of housing policies implemented to secure political support. On the contrary, the government has continuously failed to implement effective policies in this area that would facilitate easier access to housing (Mandič, 2008; Sendi, 2016).

\section{Theory 2: Homeownership as a source of wealth}

The notion of homeownership as a potential capital asset has been addressed by various authors. Saunders (1990) has described homeownership as a lucrative venture that allows people to make a lot of money. As Ray Forrest and Alan Murie (1995) have written, homeownership is an essential component of the middle class that carries a vital economic attribute. Its importance as an instrument for accumulating wealth has been increasingly discussed in the literature, especially in relation to the welfare state transformations in western Europe that have been taking place in recent decades (Kemeny, 2005; Hajer, 2009). With a lack of focus on central and eastern Europe, Srna Mandičs (2010) contribution is the first investigation of the potential of homeownership as a "wealth reservoir" in post-communist countries.

At the EU level, John Doling and Richard Ronald (2010) studied the notion of "property-based welfare", whereby they examined how homeownership may function as a pension in EU member states. They suggest that the housing wealth of homeowners "theoretically constitutes a potential reserve, supplement or even alternative to pension income" (Doling \& Ronald, 2010: 228). The basic hypothesis to be investigated is that homeowners in all EU member states can readily transform their housing equity into real income that may serve as a supplement to their (meagre) incomes at a later stage in their lives. This assumption builds upon the thesis that homeowners incur minimal housing costs in later life after paying off the mortgage they took out when younger (Castles, 1998). The theory behind this thesis is outlined by Toussaint (2011:323), who writes: "Young people save for a deposit, next they purchase a dwelling. To finance the dwelling they borrow (take out a mortgage). Gradually they repay the mortgage and build up housing equity (the value of the dwelling minus the mortgage debt). Building up housing equity can be considered as saving."

Such "saving" has been increasingly seen as a vital means of mitigating financial hardship at a later stage, particularly during retirement. The main concern here is how houses may actually function as pensions. It is thus argued that housing constitutes both an investment and a consumption good that consequently offers the owner two sources of income: "income in kind from the flow of housing services they enjoy as outright owners, and an income in cash, deriving from the release of the equity in their home" (Doling \& Ronald, 2010: 229). Like all investment goods, owner-occupied housing is therefore believed to have the potential to realise its value in the form of cash. The question is whether the desire to own one's home in Slovenia is also stimulated by a conscious intention to accumulate wealth for realising supplementary income in old age. The answer to this question is currently "no". There are several reasons for rejecting the validity of the property-based welfare theory in the case of Slovenia.

First of all, a distinction needs to be made between two principle functions of housing in Slovenia; that is, housing as shelter and housing as an investment. Under communist rule, the shelter function naturally predominated because the principle doctrine was that the government provides housing for all citizens. Issues concerning the investment and market value of housing were of no major significance. However, it has been suggested by Mandič (2010) that the shelter function was reduced after the implementation of the right to buy, thus increasing the investment function. The transformation of property from public to private ownership would of course be expected to result in the revival of its investment value. However, it is important to recognise that the shift from the shelter function to the investment function described here applies only to condominium homeownership. I argue that the shelter function still predominates in family homeownership and that this has vital implications for the potential to use housing as a source of income in old age. I also observe that it is currently not possible to recognise any serious potential for utilising family housing in Slovenia as a "supplement or even alternative to pension income", as suggested by Doling and Ronald (2010). Toussaint's statement that "the potential use of housing assets is limited: not everyone disposes of housing assets or wants to consume the asset" (Toussaint 2011: 322) certainly holds true for Slovenia. The simple reason is that Slovenians are generally almost totally immobile. When they build or buy a home, they tend to stay there forever. The 
property is, of course, always passed on to the rightful heirs when the owner dies. As has been observed elsewhere (Helderman $\&$ Mulder, 2007), bequest constitutes a very powerful disincentive to the transformation of housing equity into pension income in Slovenia. According to the findings of the DEMHOW study (Elsinga \& Mandič, 2010), which investigated the link between demographic change and housing wealth in eight EU countries, older people in Slovenia feel very strongly about keeping their property and passing it on to their heirs as "a wish to leave a bequest to one's children was recognised. Some emphasised the need to be self-sustaining, independent of others, it is better to leave something behind than be paid for by others, or leave debts" (Elsinga \& Mandič, 2010: 954).

Evidence in support of the bequest argument has been provided by the actions that followed the implementation of the Financial Social Assistance Act, which was adopted in 2010, as part of the austerity measures introduced to mitigate the impact of the financial crisis that started in 2007. The legislation provided that the government would have the right to repossess inheritance property after the death of a previous social benefit recipient, as a repayment for the financing provided from the national budget. The property in question here would, in most cases, be housing or land. According to data from the Ministry of labour, family and social affairs (2014), which is responsible for granting these allowances, approximately 13,000 (out of 40,000 at the time) social benefit recipients decided to reject the allowances in order to avoid repossession by the government after their death. Although I have no information on the remaining 23,000 that kept the allowances, there is a very strong likelihood that these were either very desperate (i.e., could not live without government financial assistance) or had no inheritance property to worry about. However, for those that rejected the allowances, the decision to withdraw their eligibility for social benefits clearly shows the importance that elderly homeowners attach to their property, especially the almost unquestionable obligation to pass it on untainted to the next generation. Pensioners would rather live in financial hardship than risk the possibility of losing their property or leaving debts to their heirs.

Other than immobility and bequest motives, there is also the element of attachment arising from the emotional value and meaning of the particular home to its owners. Accepting David Clapham's (2011: 361) observation that "definitions of home seem to vary according to the objectives of the researcher and their disciplinary and epistemological frame of reference", it is vital to stress a very specific meaning of a family house; namely, the psychological value attached to it. Because the majority of family houses are self-built according to personal taste and preferences, they tend to be considered almost priceless to the owners. Given all of these features, family houses appear on housing markets in very rare cases, if ever. In other words, housing is, above all, a consumption good that primarily offers the owner income in kind. It is vital to point out here that even financial markets' options for realising housing equity that do not require selling the property or moving do not have much appeal among elderly homeowners. The Ljubljana housing fund (the public institution responsible for housing in the country's capital city) attempted to implement a reserve mortgage financial product, but was able to conclude only one single such contract over a period of ten years.

The discourse about the potential role of homeownership as an instrument for accumulating wealth is one of the more recent contemporary theories that explains the expansion of homeownership as a key element in patterning welfare states. However, current knowledge and developments show that family homeownership in Slovenia carries with it certain characteristics that strongly disfavour the utilisation of housing wealth as a pension supplement. For now, it may be argued that these cultural and traditional values (and perhaps also unconscious psychological influences) will continue to persist for some time and hinder the applicability of the asset-based theory in Slovenia.

Theory 3: Homeownership as the result of a lack of alternative investment opportunities

A "lack of alternative investment opportunities" (or LAIO theory) is arguably the most frequently suggested explanation for the rise and expansion of homeownership in Slovenia. According to Mandič (1992: 302), "private earnings and savings - substantially enlarged by the activities of an informal economy - could not be productively invested and saved against inflation other than by channelling into individual housing". This same reason has been mentioned to explain the causes of growth in homeownership in other central and eastern European countries (cf. Tosics \& Hegedüs, 1996). According to this theory, it is claimed that under communism people had no other choice but to spend their surplus income on house-building because they could not invest their money in schemes such as securities, bonds or mutual funds. In the absence of such savings schemes, family house-building is believed to have been the only means available to households for securing a safe investment for the future. However, are these claims accurate? The greatest handicap of this theory to date is that it has not yet been backed up by any empirical evidence.

The LAIO theory mostly, if not exclusively, relates to self-construction of family houses (the level of apartment ownership in multifamily residential buildings having been relatively low under communism). It is helpful here to explain two key issues regarding the meaning of some terminology used in the text. 
First, a distinction needs to be drawn between two categories of homeownership; namely, house ownership and apartment ownership. In this article, house ownership relates to various types of family houses, mostly detached, semi-detached or row houses. Apartment ownership refers to ownership of a dwelling in a multifamily residential building, mostly in a condominium setting. Second, as mentioned above, I use the term family house. There is a well-established tradition that family houses are normally constructed in such a way as to enable grown-up children to continue to live in the parental home even after creating their own family. As such, the term family should, where appropriate, also be understood to carry the same meaning as household. The discussion on the following pages focuses on family house homeownership. However, before I continue the discussion on the LAIO theory, it is necessary to take a quick look at the statistical data on the historical development of homeownership in Slovenia.

\section{Growth of homeownership in Slovenia}

Table 1 presents data on dwellings completed by year, showing steady growth in homeownership since the mid-1950s (data are not available for before 1955). The data in the column "Private sector" show the number of dwellings completed by individual families/households (i.e., family house construction). From 1955 to 1968 , family housing completions accounted for between $38 \%$ and $46 \%$ of total new construction. In the following three years, the share of family housing construction even exceeded that of new construction in the public sector (52\% in 1969, 57\% in 1970 and 53\% in 1971). Throughout the 1970s, the level of family house construction was maintained at an annual average of $46 \%$ of the total number of completions every year. From 1983 until 2007, annual production in the family housing sector did not fall below $55 \%$ of total new construction.

The data in Table 1 show that homeownership is, and has always been, a very important tenure category. Further, the predominance of homeownership may be more clearly illustrated by the latest census data from 2012, which show that ownership accounted for $90.3 \%$ of the total housing stock and rental accounted for a mere 9.7\% (Statistical office of the Republic of Slovenia, 2012). This tenure structure clearly shows that national policies have contributed to the growth of homeownership in various ways, whereas the rented sector has been effectively decimated. Within this minimal share of rental stock, private rented tenure accounted for only $1.8 \%$ of the total stock in the 2012 census. In his study on the private rented sector in Slovenia, Richard Sendi (2016) found that the government had failed to implement any meaningful policies to allow the development and efficient operation of the private rented sector. Based on a study of concrete actions by policymakers to develop the private rented sector, Sendi concluded that the government's failure to establish a normal private rented sector in more than twenty-five years can only be explained as the reflection of an unfavourable attitude on the part of policymakers towards the private rented sector. It may be argued that this unfavourable attitude is (unconsciously) rooted in the aspiration of each individual to be a homeowner. If individuals (policymakers in this case) aspire to live in their own home, they are not likely to make an effort to pass legislation and implement policies in favour of rental tenure.

The fundamental reasons behind the popularity and growth of family house ownership may be best presented through the findings of public opinion polls conducted by Drago Kos (1984) that investigated homeownership and people's aspirations to own their home in three different years $(1969$, 1978, 1980; Table 2).

A detailed look at the figures in Table 2 makes two major observations possible. First, most respondents owned or aspired to live in a detached house with a garden. More importantly, the aspiration to own a house (detached, detached with a garden or row house) was expressed by $94.2 \%$ in the 1969 poll, $91.5 \%$ in 1978 and $92.5 \%$ in 1980 . The results of these public opinion polls therefore indicate that more than $90 \%$ of Slovenes aspire to live in one form or another of a family house. A similar survey conducted in 1991 revealed that $90 \%$ of respondents expressed a preference for owneroccupation (Mandič \& Clapham, 1996). Although the last such survey on homeownership aspiration was conducted over twenty years ago, these results are indicative of the general attitude towards homeownership and it is likely that a new survey would yield very similar results.

At this point, it is necessary to briefly discuss some factors that probably helped homeowners realise their aspiration. One of these factors was the aforementioned failure of the government to provide adequate housing for all citizens. Those that could not secure government-rented housing were thus left with no alternative but to obtain housing on their own, within the homeownership sector. In addition to the inadequate supply of government-sponsored housing, it is also important to mention the comparatively poorer quality of the dwellings in multifamily residential buildings, mostly located in high-density housing neighbourhoods. Although the figures in Table 2 show that the level of aspiration to own a dwelling in multifamily housing increased between 1969 and 1978, the aspiration for such ownership had declined by the 1980 survey. More importantly, the level of actual homeownership in multifamily housing steadily declined between the first and last survey. A large detached family house with expansive surrounding green 
Table 1. Number of dwellings completed by year, 1955-2015.

\begin{tabular}{|c|c|c|c|c|}
\hline \multirow[t]{2}{*}{ Year } & \multicolumn{2}{|c|}{ Public sector } & \multicolumn{2}{|c|}{ Private sector } \\
\hline & $n$ & $\%$ & $n$ & $\%$ \\
\hline 1955 & 2,052 & 62 & 1,258 & 38 \\
\hline 1960 & 5,926 & 73 & 2,154 & 27 \\
\hline 1965 & 6,176 & 69 & 2,766 & 31 \\
\hline 1966 & 6,194 & 63 & 3,574 & 37 \\
\hline 1967 & 5,593 & 59 & 3,801 & 41 \\
\hline 1968 & 5,089 & 54 & 4,286 & 46 \\
\hline 1969 & 4,364 & 48 & 4,724 & 52 \\
\hline 1970 & 3,959 & 43 & 5,302 & 57 \\
\hline 1971 & 4,818 & 47 & 5,451 & 53 \\
\hline 1972 & 5,408 & 53 & 4,813 & 47 \\
\hline 1973 & 4,810 & 46 & 5,688 & 54 \\
\hline 1974 & 8,076 & 58 & 5,717 & 42 \\
\hline 1975 & 9,750 & 61 & 6,143 & 39 \\
\hline 1976 & 8,536 & 59 & 5,929 & 41 \\
\hline 1977 & 8,164 & 54 & 6,811 & 46 \\
\hline 1979 & 7,422 & 54 & 6,398 & 46 \\
\hline 1980 & 6,999 & 51 & 6,673 & 49 \\
\hline 1981 & 8,281 & 56 & 6,393 & 44 \\
\hline 1982 & 7,105 & 54 & 6,140 & 46 \\
\hline 1983 & 5,634 & 45 & 6,710 & 55 \\
\hline 1985 & 5,114 & 45 & 6,138 & 55 \\
\hline 1986 & 4,887 & 38 & 8,050 & 62 \\
\hline 1987 & 3,963 & 39 & 6,249 & 61 \\
\hline 1988 & 3,684 & 37 & 6,115 & 63 \\
\hline 1989 & 2,260 & 26 & 6,281 & 74 \\
\hline 1990 & 2,246 & 29 & 5,513 & 71 \\
\hline
\end{tabular}

\begin{tabular}{|c|c|c|c|c|}
\hline \multirow[t]{2}{*}{ Year } & \multicolumn{2}{|c|}{ Public sector } & \multicolumn{2}{|c|}{ Private sector } \\
\hline & $n$ & $\%$ & $n$ & $\%$ \\
\hline 1991 & 1,332 & 22 & 4,586 & 78 \\
\hline 1992 & 1,349 & 21 & 5,143 & 79 \\
\hline 1993 & 794 & 10 & 7,131 & 90 \\
\hline 1995 & 661 & 11 & 5,054 & 89 \\
\hline 1996 & 760 & 12 & 5,468 & 88 \\
\hline 1997 & 757 & 12 & 5,328 & 88 \\
\hline 1998 & 1,228 & 19 & 5,290 & 81 \\
\hline 1999 & 569 & 11 & 4,573 & 89 \\
\hline 2000 & 1,577 & 24 & 4,883 & 76 \\
\hline 2001 & 1,048 & 15 & 5,667 & 85 \\
\hline 2002 & 1,915 & 26 & 5,350 & 74 \\
\hline 2003 & 2,290 & 35 & 4,277 & 65 \\
\hline 2004 & 2,160 & 31 & 4,844 & 69 \\
\hline 2005 & 3,032 & 40 & 4,484 & 60 \\
\hline 2006 & 2,914 & 38 & 4,624 & 62 \\
\hline 2007 & 3,869 & 46 & 4,488 & 54 \\
\hline 2008 & 5,845 & 58 & 4,126 & 42 \\
\hline 2009 & 4,400 & 51 & 4,161 & 49 \\
\hline 2010 & 2,499 & 39 & 3,853 & 61 \\
\hline 2011 & 2,028 & 37 & 3,439 & 63 \\
\hline 2012 & 1,298 & 30 & 3,009 & 70 \\
\hline 2013 & 828 & 24 & 2,656 & 76 \\
\hline 2014 & 607 & 19 & 2,556 & 81 \\
\hline 2015 & 354 & 13 & 2,422 & 87 \\
\hline
\end{tabular}

Source: Statistical office of the Republic of Slovenia.

Table 2. Homeownership and aspiration to own a house (surveys, 1969, 1978, 1980).

\begin{tabular}{lcccccc}
\hline House type & \multicolumn{2}{c}{1969} & \multicolumn{2}{c}{1978} & \multicolumn{2}{c}{1980} \\
\hline & Owner-ship & Aspiration to own & Owner-ship & Aspiration to own & Owner-ship & Aspiration to own \\
\hline $\begin{array}{l}\text { Detached house with } \\
\text { garden }\end{array}$ & 35.1 & 53.5 & 48.7 & 63.5 & 49.3 & 61.0 \\
\hline Detached house & 32.6 & 36.7 & 13.7 & 25.0 & 17.5 & 28.7 \\
\hline Row house & 3.7 & 4.0 & 3.8 & 3.0 & 3.0 & 2.8 \\
\hline $\begin{array}{l}\text { Low-rise multifamily resi- } \\
\text { dential building }\end{array}$ & 15.7 & 1.9 & 13.1 & 3.5 & 9.7 & 2.8 \\
$\begin{array}{l}\text { (up to 10 floors) } \\
\text { High rise multifamily }\end{array}$ & 12.9 & 3.9 & 20.7 & 5.0 & 20.5 & 4.7 \\
\hline $\begin{array}{l}\text { residential building } \\
\text { Total }\end{array}$ & 100 & 100 & 100 & 100 & 100 & 100 \\
\hline
\end{tabular}

Source: Kos (1984).

space was clearly a more attractive and better choice for those left out in the public housing allocation process.

In addition to the inadequacy of supply in terms of both quantity and quality, there were also economic considerations that need to be taken into account. Kos (1984) also found that the cost of a square metre of public housing was higher compared to the average cost of a square metre of self-built housing. "This is certainly paradoxical [given that the government was supposed to provide housing at low cost], but it also reflects the low price of agricultural land that most family houses are built on. It is therefore understandable that family housing 
construction provides a cheaper housing alternative for those that cannot afford public housing and cannot secure public rented housing" (Kos, 1984: 18).

It is possible that the lack of supply and comparatively poorer quality of public housing may have influenced individuals' decisions to build housing. Regrettably, however, there is no evidence to conclude that these factors played a significant role in the development of and growth in homeownership. However, Kos's finding that the cost of building a house was comparatively low was clearly a major incentive for those that aspired to become homeowners.

The homeownership phenomenon in Slovenia thus requires more detailed investigation to better understand why it is the most desired type of tenure. Against this background, I continue the discussion with an analysis of the validity of the LAIO theory.

\section{Examining the LAIO theory}

The LAIO theory is rather simplistic and unconvincing for several reasons. First of all, it has already been explained that in the majority of cases family houses were built through selfconstruction. It is also important to point out that a very large majority of self-built homes were constructed on land owned by the future homeowner or their relatives (Kos, 1984). This therefore means that the potential house-builder would require financing only for the construction itself, with no expense incurred for purchasing the land. As such, the total cost of acquiring a house was considerably reduced. So, rather than a heavy cash investment, self-build homeowners invested their own effort in order to fulfil their ultimate dream of owning a house. Gilbert (1999) terms such capital assets "sweat equity" in his discussion on the self-construction housing mechanism that enables large numbers of households to acquire homeownership in Mexico. The usual practice in Slovenia would be for potential homebuilders to seek (and expect) the assistance of relatives, neighbours and friends. Together, they would carry out all the construction work, except for that requiring professional expertise (such as roofing, water and electrical installations, etc.). This method of house-building would normally prolong the construction period, but it was cheaper than contracting a professional construction company. In the majority of cases it took up to ten years or even longer to complete the house. This may be seen as an indication that the majority of family house builders did not have much money to spare. The only financial input they required was the money to buy the necessary building materials, which, as already explained, were available at lower prices. The major expense in the entire process would be for hiring professionals for the more complex work that they could not perform themselves.) Most workers' wages were modest and there was not much surplus money for households to invest in securities, even if such options had been available. I therefore conclude here that the non-existence of investment opportunities cannot be a major causal factor in the development and growth of homeownership in Slovenia. The major motivation for undertaking the cumbersome task of building a house was thus the desire to live in one's own house.

The third reason for rejecting the LAIO theory is that housebuilding has eventually been relinquished to professionals. Although family house-building is continuing at similar levels as before, the level of self-building activity has been declining since the introduction of the market economy system. However, this decline is not due to the availability of alternative investment opportunities that emerged after the shift to a market economy. Although no official study has been conducted in this area yet, there are several reasons for the decline of the practice. First, the rescheduling of working hours (starting work later in the morning) considerably reduced the amount of free afternoon daylight time that was previously available to those that wished to engage in self-construction. Second, the adoption of the market economy introduced several systemic and regulatory changes, including a law that limited the size of self-built dwellings to $250 \mathrm{~m}^{2}$. Larger houses must be built by professionals. My thesis is that this limitation has played out as a disincentive to some potential self-builders. Third, the shift to a market economy also led to a gradual increase in household incomes, which steadily grew from the 1990s throughout the 2000s, until the global financial crisis in 2008. With the rise in incomes, bank loans increasingly became more accessible (Cirman, 2006), which consequently enabled and encouraged potential homeowners to take out housing mortgages as a supplement to their savings to purchase dwellings or hire professional builders.

Finally, I reject the LAIO theory in view of the situation that followed the emergence of alternative investment opportunities, the lack of which is claimed to have been the major reason for the growth of homeownership in the country. After almost fifty years of absence, the Slovenian stock exchange was reintroduced in 1989. Since then, people have had several options for investing surplus income (government bonds, company shares, mutual funds, insurance-linked securities, etc.). In the absence of any relevant empirical study, I suggest that those investing in securities usually do so with the intention of eventually purchasing a home, either for themselves or their children. One reasonable explanation for this is that the majority of parents consider it an obligation to provide a major share (if not 100\%) of the cost of housing for their grown-up children. The key point is that, whatever form of saving is chosen, the savings would eventually transform into homeownership. As 
already shown, homeownership remains the ultimate goal of the majority of Slovenian families. The statistical data presented above on the level of homeownership supports these assertions.

\section{Conclusion}

I started this discussion with a brief review of Saunder's comprehensive study on major homeownership theories. I argued that the Marxist theories cannot apply to the Slovenian situation because they describe circumstances that are diametrically opposite to those that prevailed in Slovenia at the time. Although homeownership was not entirely forbidden by the communist regime, there was no deliberate government policy aiming to encourage it to legitimise upper-class private property ownership. Communist regimes did not have upper classes (at least officially). I also refuted the theory that homeownership has grown as a consequence of government policies implemented with the deliberate intention to secure voter support. However, I have accepted that various government policies implemented at various times did encourage the development of homeownership and contributed to its growth.

I have also given several reasons to reject the theory suggesting that the level of homeownership has expanded because people intend to use the wealth so acquired to supplement their pension incomes in old age. The specific characteristics of homeownership in Slovenia - predominance of the shelter function over the investment function of housing, immobility and especially self-construction practices and bequests - render inapplicable the notion of property-based welfare as a viable explanation for the expansion of homeownership.

I identified the LAIO theory as the most popularly applied explanation for the growth of homeownership in Slovenia, examined its validity and stated several reasons for rejecting it. I essentially argued that those that set out to build their own houses did not have much surplus income that they would have invested otherwise. If they had, they probably would have hired professionals to do the job for them and avoided the heavy manual labour, which also jeopardised their health. Those wanting to acquire their own home were willing to invest their physical energy and renounce other activity (e.g., leisure) to achieve this major objective. I therefore argue that the impelling motive to build was not a lack of alternative investment opportunities, but simply the desire to own a home.

This view leads to the theory that I advance in the conclusion as the main explanation for excessive homeownership in Slovenia. Like Saunders (1990), I argue that the desire to own a home must be examined and understood in terms of human behaviour. Prior to Saunders' publication, Irving Welfeld (1988) described the stable consumer preference for homeownership in the United States as part of human nature: "The lusting after ownership is a near universal and ancient attribute of mankind" (1988: 59). Following this school of thought, I propose that there is a natural preference for homeownership as opposed to renting. Saunders explained this natural preference in terms of people's "possessive instinct and the desire to mark out their own territory" (1990: 70). Gurney (1999), on the other hand, cautioned that, although homeownership is now increasingly seen as "the norm" in the UK and renters are viewed as an "outsider group", this urge to own should not necessarily be seen as an innate "natural" preference. This must be understood as a warning against over-simplifying such a complex phenomenon. The justification of my proposal is thus urgent.

I argue that a powerful human instinct has been the driving force behind the growth of homeownership in Slovenia. I suggest that the desire to own one's home is primarily a natural aspiration as opposed to a socially driven urge promoted by politicians to implement development policies or realise personal political agendas. However, I also accept that the strong instinct to own one's home may have gradually evolved into what today appears to be a culture or tradition. As shown by the results of surveys on homeownership, there is no doubt that people simply want to own their home, especially a family house. Is this also connected with acquiring an important status symbol, as suggested by some writers? This proposition cannot be rejected outright. This is another issue that needs to be investigated through focused research because it is currently not possible to establish which proportion of homeownership emerges as a natural aspiration and which might be the result of an urge to acquire social status.

For now, I am pursuing the theory that the instinct to own one's home is the major factor that has propelled the development and growth of homeownership to such a high level. The literature offers some explanations of human behaviour in relation to property ownership (Tinbergen, 1951; Retsinas \& Belsky, 2002; Krulik \& Novakova, 2011). Anthropologists believe that at a certain period in the evolution of mankind humans settled down in an agricultural society. This type of occupation of space required the acquisition and possession of land, a notion anthropologists describe as territoriality. In their discussion on territoriality in relation to animals and humans, Oldrich Krulik and Jaroslava Novakova (2011: 1) state that "delimiting personal space is one of the essential features of human behaviour". Human behaviour, on the other hand, is always triggered as a reaction to something. Nikolaas Tinbergen (1951: 15) has defined human behaviour as "a reaction in so far as it is, to a certain extent, dependent on external stimulation. It is spontaneous in so far as it is also dependent 
on internal causal factors, or motivational factors, responsible for the activation of an urge or drive."

In the case of the desire to own one's home, human behaviour may be understood to be both a reaction to internal causal factors (an instinct) as well as external stimulation (cultural influence). Both the instinct and external stimulation may be read in the statement that "Humans are creatures who are wired to learn certain things, to expend certain energies, and to respond to certain stimuli in ways that have been built into them by the peculiar evolutionary history of the species" ( $\mathrm{Ti}$ ger \& Fox, 1971: 233).

This statement provides a suitable basis for the fundamental thesis that I propose as an alternative explanation for the development of homeownership in Slovenia. While accepting an element of external stimulation in the form of tradition that has, arguably, turned into a culture, I believe that it is internal causal factors that activate the "urge or drive" (Tinbergen, 1951) to own one's home. As held by Lionel Tiger and Robin Fox (1971: 233), "The rights of man are not cultural inventions but statements about the nature of the creature. Men are not simply the creatures of culture, they are the creatures that create culture, because that is the kind of creatures they are."

The self-construction mechanism of acquiring homeownership is certainly a tradition or culture that facilitated easier access to family house ownership in the past. However, the principal theory I advance here is that the development and growth of homeownership in Slovenia has primarily been propelled by the natural urge to own one's home.

\section{Richard Sendi}

Urban Planning Institute of the Republic of Slovenia, Ljubljana,

Slovenia

E-mail: richards@uirs.si

\section{Notes}

[1] The privatisation of the public housing stock had several objectives. First, after adopting an "enabling" approach instead of the "providing" one, the government had to eliminate the large social housing stock, which was burdening the national budget with high maintenance costs. Second, the government was able to acquire much-needed additional financial resources during the critical period of establishing an independent economic base after secession from the Yugoslavia. Third, the measure enabled the redistribution of some of the wealth accumulated as "public property" during communist rule to citizens that had financed and contributed to its creation through monthly payments. Finally, it was also hoped that private homeownership would lead to greater efficiency in managing and maintaining multifamily housing (Sendi, 2009).

\section{References}

Ball, M. (1983) Housing policy and economic power. London, Methuen. DOI: $10.4324 / 9780203472613$
Castles, F. (1998) The really big trade-off: Home ownership and the welfare state in the new world and the old. Acta Politica, 33(1), pp. 5-19.

Cirman, A. (2006) Housing tenure preferences in the post privatisation period: The case of Slovenia. Housing Studies, 21(4), pp. 360-376. DOI: 10.1080/02673030500391213

Cirman, A. \& Sendi, R. (2016) Housing finance in Slovenia: From a national housing fund to a bank-driven system. In: Lunde, J. \& Whitehead, C. (eds.) Milestones in European housing finance, pp. 341-357. Chichester, UK, John Wiley \& Sons. DOI: 10.1002/9781118929421.ch20

Clapham, D. (2011) The embodied use of the material home: An affordable approach. Housing, Theory and Society, 28(1), pp. 34-54. DOI: 10.1080/14036096.2011.564444

DiPasquale, D. \& Gleaser, E. L. (1999) Incentives and social capital: Are homeowners better citizens? Journal of Urban Economics, 45(2), pp. 354-384. DOI: 10.1006/juec.1998.2098

Dol, K., \& Haffner, M. (eds.) (2010) Housing statistics in the European Union, 2010. Delft, Delft University of Technology.

Doling, J. \& Ronald, R. (2010) Property-based welfare and European homeowners: How would housing perform as a pension? Journal of Housing and the Built Environment, 25, pp. 227-241. DOI: 10.1007/s10901-010-9184-7

Elsinga, M. \& Hoekstra, J. (2005) Homeownership and housing satisfaction. Journal of Housing and the Built Environment, 20(4), pp. 401-424. DOI: 10.1007/s10901-005-9023-4

Elsinga, M. \& Mandič, S. (2010) Housing as a piece in the old-age puzzle. Teorija in praksa, 47(5), pp. 940-958.

Forrest, R. \& Murie, A. (eds) (1995) Housing and family wealth - comparative international perspectives. London, Routledge.

Giddens, A. (1984) The constitution of society. Cambridge, Polity Press.

Gilbert, A. (1999) A home is for ever? Residential mobility and homeownership in self-help settlements. Environment and Planning A, 31, pp. 1073-1091. DOI: 10.1068/a311073

Gilbert, A. (2008) Viewpoint. Slums, tenants and home-ownership: On blindness to the obvious. International Development Planning Review, 30(2), pp. i-x. DOI: 10.3828/idpr.30.2.1

Gilbert, A. \& Varley, A. (1990) The Mexican landlord: Rental housing in Guadalajara and Puebla. Urban Studies, 27(1), pp. 23-44. DOI: 10.1080/00420989020080021

Gurney, C. M. (1999) Pride and prejudice: Discourses of normalization in public and private accounts of home ownership. Housing Studies, 14, pp. 163-183. DOI: 10.1080/02673039982902

Hajer, J. (2009) Home-ownership for low-income households: Outcomes for families and communities. Canadian Centre for Policy Alternatives. Available at: http://www.policyalternatives.ca/sites/default/files/uploads/publications/Manitoba_Pubs/2009/Home_ownership_for_Low_Income_Households_April2009.pdf (accessed 14 April 2013).

Hegedüs, J., Mark, K. \& Tosics, I. (1996) Uncharted territory: Hungarian housing in transition. In: Struyk, R. J. (ed.) Economic restructuring of the former Soviet bloc: The case of housing, pp. 71-138. Washington, DC, The Urban Institute Press.

Hegedüs, J. \& Tosics, I. (1992) Housing reforms in Hungary. In: Turner, B. Hegedüs, J. \& Tosics, I. (eds.) The reform of housing in eastern Europe and the Soviet Union, pp. 151-178. London, Routledge.

Helderman, A. \& Mulder, C. (2007) Intergenerational Transmission of Homeownership: The Roles of Gifts and Continuities in Housing Market Characteristics. Urban Studies, 44 (2), pp. 231-247. DOI: 10.1080/00420980601075018 
Kemeny, J. (1981) The myth of home ownership. London, Routledge \& Kegan Paul.

Kemeny, J. (2005) "The really big trade-off" between home ownership and welfare: Castles' evaluation of the 1980 thesis and a reformulation 25 years on. Housing, Theory and Society, 22(2), pp. 59-75.

Koleva, M. \& Dandolova, I. (1992) Housing reforms in Bulgaria: Myth or reality? In: Turner, B., Hegedüs, J. \& Tosics, I. (eds.) The reform of housing in eastern Europe and the Soviet Union, pp. 28-40. London, Routledge.

Kos, D. (1984) Predstavitev rezultatov javnomnenjskih raziskav o rezidencialnih aspiracijah. Research report. Ljubljana, Urban Planning Institute of the Republic of Slovenia.

Krulik, O. \& Novakova, J. (2011) Image of the place and perception of security. The Science for Population Protection, 1/2011. Available at: http://www.population-protection.eu/attachments/038_vol3n1_krulik_novakova_eng.pdf (accessed 25 Jun. 2014).

Lowe, S. \& Tsenkova, S. (eds.) (2003) Housing change in east and central Europe: Integration or fragmentation? Aldershot, Ashgate.

Mandič, S. (1992) Reformism in Yugoslavia. Introductory remarks. In: Turner, B., Hegedüs, J. \& Tosics, I. (eds.) The reform of housing in eastern Europe and the Soviet Union, pp. 296-307 London, Routledge.

Mandič, S. (2008) Home-leaving and its structural determinants in western and eastern Europe: An exploratory study. Housing Studies, 23(4), pp. 615-637. DOI: 10.1080/02673030802112754

Mandič, S. (2010) The changing role of housing assets in post-socialist countries. Journal of Housing and the Built Environment, 25(10), pp. 213226. DOI: 10.1007/s10901-010-9186-5

Mandič, S. \& Clapham, D. (1996) The meaning of homeownership in the transition from socialism: The example of Slovenia. Urban Studies, 33(1), pp. 83-97. DOI: 10.1080/00420989650012130

Marinšek, E. (1983) Financiranje družbeno usmerjene stanovanjske gradnje. Research report. Ljubljana, Urban Planning Institute of the Republic of Slovenia.

McCabe, B. J. (no date) Are homeowners better citizens? New evidence on the behavioural effects of homeownership for local civic participation. New York: New York University, Department of Sociology. Available at: https://files.nyu.edu/bjm305/public/McCabe_Civic_Participation. pdf (accessed 24 Jan. 2013).

Megbolugbe, F. \& Linneman, D. (1993) Home ownership. Urban Studies, 30(4/5), pp. 659-682. DOI: 10.1080/00420989320081861

Michalovic, P. (1992) Housing in Czechoslovakia: Past and present problems. In: Turner, B., Hegedüs, J. \& Tosics, I. (eds.) The reform of housing in eastern Europe and the Soviet Union, pp. 46-61. London, Routledge.

Ministry of Labour, Family and Social Affairs (2014) Družinski prejemki, pravice iz zavarovanja za starševsko varstvo. Available at: http://www. mddsz.gov.si/si/uveljavljanje_pravic/statistika/ (accessed 18 Dec. 2016).

Munro, M. (2007) Evaluating policy towards increas-

ing owner occupation. Housing Studies, 22(2), pp. 243-260.

DOI: 10.1080/02673030601132896

Obeng-Odoom, F. \& Seong Jang, H. (2016) Migrants and the transformation of local neighbourhoods: A study of the socioeconomic transformation of Lidcombe, Australia. Urbani izziv, 27(1), pp. 132-148. DOI: 10.5379/urbani-izziv-en-2016-27-01-004

Retsinas, N. P. \& Belsky, E. S. (2002) Examining the unexamined goal. In: Retsinas, N. P. \& Belsky, E. S. (eds.) Low-income home ownership: Examining the unexamined goal, pp. 1-12. Cambridge, Joint Centre for Housing Studies.
Rohe, W. M. \& Stewart, L. S. (1996) Homeownership and neighbourhood stability. Housing Policy Debate, 7(1), pp. 37-81. DOI: 10.1080/10511482.1996.9521213

Rohe, W. M., Van Zandt, S. \& McCarthy, G. (2001) The social benefits and costs of homeownership: A critical assessment of the research. Harvard University, Joint Center for Housing Studies.

Rohe, W. M., Van Zandt, S. \& McCarthy, G. (2002) Home ownership and access to opportunity. Housing Studies, 17(1), pp. 51-61. DOI: 10.1080/02673030120105884

Ronald, R. (2008) Between investment, asset and use consumption: The meaning of home ownership in Japan. Housing Studies, 23(2), pp. 233251. DOI: $10.1080 / 02673030801893099$

Rossi, P. H. \& Weber, E. (1996) The social benefits of homeownership: Empirical evidence from national surveys. Housing Policy Debate, 7 (1), pp. 1-35. DOI: 10.1080/10511482.1996.9521212

Saunders, P. (1990) A nation of home owners. London, Unwin Hyman Ltd.

Sendi, R. (1999) Private rented housing in Slovenia: A non-existent housing sector? Netherlands Journal of Housing and the Built Environment, 14(3), pp. 309-322. DOI: 10.1007/BF02496684

Sendi, R. (ed.) (2007) Stanovanjska reforma: pričakovanja, potrebe, realizacija. Urbani izziv publikacije. Ljubljana, Urban Planning Institute of the Republic of Slovenia.

Sendi, R. (2009) Management of privatised housing: Slovenia. In: Gruis, V., Tsenkova, S. \& Nieboer, N. (eds.) Management of privatised housing: Internal policies and practice, pp. 229-255. Oxford, Wiley-Blackwell. DOI: 10.1002/9781444322613.ch12

Sendi, R. (2016) Is the private rented sector desirable in Slovenia? Examining the role of the state in the development of the sector. Urbani izziv, 27(2), pp. 112-124. DOI: 10.5379/urban-izziv-en-2016-27-02-003

Shlay, A. B. (2006) Low-income homeownership: American dream or delusion? Urban Studies, 43(3), pp. 511-531. DOI: 10.1080/00420980500452433

Statistical Office of the Republic of Slovenia (2012) SI-Stat Data Portal. Available at: http://pxweb.stat.si/pxweb/dialog/statfile1.asp (accessed 18 May 2013).

Telegarsky, J. P. \& Struyk, R. (1991) Toward a market-oriented housing sector in Eastern Europe: Developments in Bulgaria, Czechoslovakia, Hungary, Poland, Romania, and Yugoslavia. Washington, DC, the Urban Institute Press.

Tiger, L. \& Fox, R. (1971) The imperial animal. New York, Holt, Rinehart and Winston.

Tosics, I. \& Hegedüs, J. (1996) Housing in south-eastern Europe. In: Clapham, D., Hegedus, J. Kintrea, K, Tosics, I. \& Kay, H. (eds.) Housing privatisation in eastern Europe, pp. 169-189. London, Greenwood Press.

Toussaint, J. (2011) Housing assets as a potential solution for financial hardship: Household's mental accounts of housing wealth in three European countries. Housing, Theory and Society, 28(4), pp. 320-341. DOI: $10.1080 / 14036096.2011 .554853$

Tinbergen, N. (1951) The study of instinct. Chapter 2. Oxford, Oxford University Press. Available at: http://jackknife.med.yale.edu/nsci590-2009/ pdfs/tinbergen-instinct.pdf (accessed 15 Nov. 2012).

Turner, B., Hegedüs, J. \& Tosics, I. (eds.) (1992) The reform of housing in eastern Europe and the Soviet Union. New York, Routledge.

UN-HABITAT (2003) Rental housing: An essential option for the urban poor in developing countries. Nairobi, UNHCR.

Welfeld, I. (1988) Where we live. A social history of American housing. New York, Simon and Schuster. 